\title{
Impact of Bisphenol A on the Physicochemical and Bacteriological Characteristics of Water in Storage Tanks from various Locations in Salem University Lokoja, Kogi State, Nigeria
}

\author{
${ }^{1,2 *}$ UDOCHUKWU, U; ${ }^{2}$ OLANNYE, PG \\ ${ }^{1}$ Department of Biosciences, Salem University, P.M.B. 1060, Lokoja, Kogi State, Nigeria \\ ${ }^{2}$ Department of Microbiology, University of Benin, Benin City, Edo State, Nigeria \\ *Corresponding Author Email: rev.dr.ud@gmail.com
}

\begin{abstract}
This study examined the impact of Bisphenol A (BPA) on the physicochemical and bacteriological characteristics of water in storage tanks in Salem University Lokoja. Borehole water samples were collected from three (3) locations within the University environment and stored in a jerry can for analysis. Total Heterotrophic Bacteria Count (THBC) in water samples ranged from $1.00 \pm 0.30 \times 10^{4}$ at week 0 to $8.95 \pm 1.00 \times 10^{4} \mathrm{cfu} / \mathrm{ml}$ at week 3 , while the total coliform count (TCC) also ranged from $1.30 \pm 0.15 \times 10^{4}$ to $7.11 \pm 0.82 \times 10^{4} \mathrm{cfu} / \mathrm{ml}$. TCC and THBC were found to be higher than the NSDWQ Standard. The identified isolates from the borehole samples were Escherichia coli, Pseudomonas aeruginosa, Streptococcus faecalis, Bacillus cereus, Staphylococcus epidermidis and Serretia spp. Bisphenol A (BPA) was not detected in week 0 , after week 3, components of Bisphenol A detected were methyl chloride, Benzene and Dichlorobenzene and their highest values were $0.054 \pm 0.033,0.021 \pm 0.020$ and $0.055 \pm 0.062 \mathrm{mg} / \mathrm{l}$ respectively. The $\mathrm{pH}$, Turbidity, Total suspended solids, BOD and conductivity reduced as storage increased. Magnesium and calcium for sample B were found to have the highest value of 0.31 and $1.73 \mathrm{mg} / \mathrm{l}$ respectively. Storage of water for a long period of time should be discouraged as it could trigger increased leaching of BPA into the water which will affect its physicochemical and microbiologically quality.
\end{abstract}

\section{DOI: https://dx.doi.org/10.4314/jasem.v24i2.5}

Copyright: Copyright (C) 2020 Udochukwu and Olannye. This is an open access article distributed under the Creative Commons Attribution License (CCL), which permits unrestricted use, distribution, and reproduction in any medium, provided the original work is properly cited.

Dates: Received: 16 November 2019; Revised: 11 January 2020; Accepted: 22 February 2020

Keywords: Bacteria, Bisphenol A, Storage Water Tanks, Drinking Water Quality.

Good quality water guarantees public health, protection of the environment and sustainable development (Ranjini et al., 2010). Water of good quality is of basic importance to human physiology and man's continued existence depends very much on its availability (Lamikara, 1999; FAO, 1997). By 2025 , one-third of the population of the developing world will face severe water shortage (Sota et al., 2005). Contaminated water is a global public health threat placing people at risk of a host of diarrhoeal and other illness as well as chemical intoxication. The major risk to human health is faecal contamination of water supplies (Okonko et al., 2009). A significant proportion of the world's population use potable water for drinking, cooking, personal and home hygiene (WHO, 2005). Before water can be described as potable, it has to comply with certain physical, chemical and bacteriological standards which are designed to ensure that the water is potable and safe for drinking (Atuanya et al., 2016). Over 50,000 people die daily due to water borne diseases (Marque et al., 2003). About 2.3 billion people Worldwide have mortality and morbidity associated with water related ailment. In order to improve the bacteriological quality of water consumed by members of rural households, it is essential to address the quality of stored drinking water and the conditions under which the water supplies are stored. Storing of water in tanks for days or weeks increases bacteria load and leaching of Bisphenol A and as such reduces the quality of water (Jagals et al., 1999: Adeghe and Emejulu, 2016). According to (Eniola et al., 2007), storage generally reduces the numbers of bacteria which is in contrast to (WHO, 2005) which identified water as a major components for bacteria growth. Several technologies for the treatment of household water in developing countries have been developed to improve the chemical and bacteriological quality of the water and to reduce waterborne diseases (Mintz et al., 1995). These technologies include physical methods such as boiling, heating, sedimentation, filtration, exposure to ultraviolet radiation from sunlight and chemical disinfection with agents such as sodium hypochlorite, chlorine (Mintz et al., 1995; Sobsey, 2002). Bacteria reactivate faster in dechlorinated water than in chlorinated water (Sobsey, 2002). BPA is widely used for mass production of plastic (polycarbonates) and epoxy resin (Morrissey et al., 1987; Staples et al., 1998). For many years, BPA was treated as a non-toxic compound with no negative impact on humans and animals. BPA-based products were commonly used to mention lacquers for cans and vessels for storage of food, water, and medicines (Staples et al., 1998). Since the second half of the 90 -ties, numerous reports have arrived stating a negative influence of BPA on human health (Biles et al., 1997; Del-Olmo et al., 1997). BPA 
has been classified as xenobiotic endocrine disruptor, disrupting the balance of the hormonal system (Moriyama et al., 2002). Stored water and Bisphenol A are like two components that go together when subjected to high temperature and over a long period of storage (Del-Olmo et al., 1997). Therefore, auditing and monitoring of chemical and bacteria quality of drinking water is an essential aspect of water quality. Therefore, this study examined the physicochemical and bacteriological characteristics of water in storage tanks from various locations in the Salem University Lokoja, Kogi State.

\section{MATERIALS AND METHOD}

Sample collection and borehole water physiochemical analysis: Borehole Water sample was collected from storage tank in three (3) different locations within the University premises: Hostel (Sample A), the Cafeteria (Sample B) and at the College of Natural and Applied Sciences (CNAS) (Sample C). The samples were spread into three different jerry can which represents our storage tank. The samples were kept outside and sealed to avoid contamination. A glass jar was used at the point of collection for analysis. The samples were analysed for their physicochemical, bacteriological and Bisphenol A composition. The physicochemical parameters analysed were $\mathrm{pH}$, chloride, sodium, electricity conductivity, Iron, total dissolved, biochemical oxygen demand, total suspended solid, calcium, manganese, zinc, copper, sulphide and phosphorus according the method described by (Aydin, 2007)

Isolation and Identification of bacteria: Nutrient agar was used in the isolation and enumeration of bacteria using the pour plate method. The pure culture was then transferred into nutrient agar slants for biochemical test. Nutrient and MacConkey agar were used to enumerate the bacteria in the water samples (Cheesbrough, 2000). Identification of isolates was based on cultural, morphological and biochemical characteristics following standard methods (Garrity et al., 2005; Holt et al., 2000).

Analysis of Bisphenol A (BPA) in borehole water: Hewlett Packard 5890 series II gas chromatograph equipped with an Agilent 7683B injector (Agilent Technologies, Santa Clara, CA, USA), a 30m, $0.25 \mathrm{~mm}$ i.d. HP-5MS capillary column (Hewlett-Packard, Palo Alto, CA, USA) coated with 5\% phenylmethylsiloxane (film thickness $0.25 \mathrm{um}$ ) and an Agilent 5975 mass selective detector (MSD) was used to separate and qualify the (BPA) compounds. The samples were injected in the split less mode at an injection temperature of $300^{\circ} \mathrm{C}$. The transfer line and iron source temperature were $280^{\circ} \mathrm{Cand} 200^{\circ} \mathrm{C}$. The column temperature was initially held at $40^{\circ} \mathrm{C}$ for 1 minute, raised at $120^{\circ} \mathrm{C}$ at the rate of $25^{\circ} \mathrm{C} /$ minute, then to $60^{\circ} \mathrm{C}$ at the rate of $10^{\circ} \mathrm{C} /$ minute, and finally to $300^{\circ} \mathrm{C}$ at the rate of $5^{\circ} \mathrm{C} /$ minute, held at the final temperature for 15 minute. Detector temperature was kept at $280^{\circ} \mathrm{C}$. Helium was used as a carrier gas at a constant flow of $1 \mathrm{ml} /$ minute. Mass spectrometry was acquired using the electron ionization (EI) and selective ion monitoring (SIM). Fifty $\mathrm{ml}(50 \pm 0.01 \mathrm{ml})$ water was measured, and $100 \mathrm{ml}$ of dichloromethane (DCM) via separating funnel and shacked for $30 \mathrm{mins}$ for BPA extraction (Dean and Xiong 2000). This separating funnel was clamp and a mixture was allowed to separate out. After separation the DCM portion was collected. The process was repeated three times for complete extraction (FAO, 1997). Blanks were prepared following the same procedure without the sample. The standard sample used for quality control was prepared by adding standard solution (BPA) to DCM. All extracts were separated, and activated copper was added to the combine extract for desulphurization. After subsequent filter over anhydrous sodium sulphate, the solution was concentrated to $1.0 \mathrm{ml}$ using a rotary evaporator, an internal standard mixture (vinyl chloride) solution was run with the extract for quality control check using Hewlett Packard 5890 series II gas chromatograph with mass selective detection (GC-MS) (Dean and Xiong, 2000).

\section{RESULT AND DISCUSSION}

The physicochemical analysis result is shown in (Table 1). The result showed that all physicochemical parameters for sample A were compliance with the Nigerian Standard of Drinking Water, while the ammonium $\left(\mathrm{NH}_{3}{ }^{+}\right)$and calcium $\left(\mathrm{Ca}^{2+}\right)$ content for sample $\mathrm{B}$ and $\mathrm{C}$ exceeded the maximum limit of the Nigerian Standard of Drinking Water. Also the iron $\left(\mathrm{Fe}^{2+}\right)$ content for sample B exceeded the required limit. The $\mathrm{pH}$ value for sample $\mathrm{B}(6.6 \pm 0.06$ to $6.47 \pm 0.97)$ exceeded the maximum limit of the Nigerian Standard of Drinking Water. For total heterotrophic bacteria count, Sample B had the highest count which ranged from $6.57 \pm 0.93$ to $7.4 \pm 0.67 \mathrm{cfu} / \mathrm{ml}$ between week 0 and week 1 while sample $\mathrm{C}$ had the highest count for week 2 and 3 which were $8.95 \pm 1.00 \mathrm{cfu} / \mathrm{ml}$ and $4.26 \pm 0.42 \mathrm{cfu} / \mathrm{ml}$ respectively (Table 2). The coliform bacteria count showed that Sample B recorded the highest count for week 0 which was $4.01 \pm 0.57 \mathrm{cfu} / \mathrm{ml}$ while sample $C$ had the highest count for week 1,2 and 3 which are $6.16 \pm 0.61,3.09 \pm 0.31$ and $7.11 \pm 0.82 \mathrm{cfu} / \mathrm{ml}$ (Table $3)$. Possible bacteria pathogens identified from the water sample were Escherichia coli, Pseudomonas aeruginosa, Serretia spp. and Staphylococcus epidermidis (Table 4). The Distribution of bacterial 
isolate in borehole water samples was investigated, and it was observed that Escherichia coli had the highest percentage occurrence with $30.5 \%$ and Serretia spp. (11.1\%) with least percentage occurrence (Table 5). The Bisphenol A contingents were identified from the water samples. It was observed that hexane, vinyl chloride, toluene and tetrachloroethylene were not detected in the water samples. Dichlorobenzene and methylene chloride had the highest value of $0.055 \pm 0.062$ and $0.054 \pm 0.033$ $\mathrm{mg} / \mathrm{l}$ respectively while benzene had the lowest value of $0.021 \pm 0.020 \mathrm{mg} / \mathrm{l}$ (Table 6). The physiochemical parameters were critically analyzed for a period of 3 weeks. There was gradual increase in the $\mathrm{pH}$ of water samples from week 0 to week 3 , the $\mathrm{pH}$ of all samples ranged from 5.33 to 6.6. The $\mathrm{pH}$ of Sample B is in line with Nigeria Standard of Drinking Water Quality (NSDWQ) of 6.5-8.5. This shows that as storage increases $\mathrm{pH}$ also increases this is in agreement with Aydin. (2007) who recorded increased $\mathrm{pH}$ as storage increases. The $\mathrm{pH}$ of Sample A and $\mathrm{C}$ for both week 0 and week 3 are below (NSDWQ). The pH of Sample $B$ is in line with NSDWQ standard (NSDWQ, 2007). The $\mathrm{pH}$ of water samples at week 0 were suitable for bacteria proliferation, a neutral $\mathrm{pH}$ will support growth of a large number of bacteria (Madigan et al., 2000). The turbidity of all water samples ranges from 0.07 to $0.6 \mathrm{ntu}$. There was decreased in turbidity as storage increased, low turbidity is often expected not to exceed 5 ntu (EPA, 2003).

The total dissolved solids in Sample A and $\mathrm{C}$ reduced as storage increased, an increase was observed in Sample B. Total dissolved solids (TDS) of all the samples were lower than NSDWQ Standard OF $500 \mathrm{mg} / \mathrm{L}$. Total dissolved solids in drinking water has been associated with sewage urban runoff, natural sources and industrial waste water (NSDWQ, 2007). This finding is contrary to the observation of (Ballester and Sunyer, 2000) whose TDS were in line with NSDWQ standard. Total suspended solid (TSS) ranged from $0.25-2.68 \mathrm{mg} / \mathrm{l}$ which decreased as storage increased. The biological oxygen demand (BOD) reduced also followed suit as there is no standard limit to BOD. Cadmium and lead were not detected in the water samples at week zero, but at week 3 components of cadmium and lead were detected (Table 1). The presence of sodium, calcium and magnesium salts in water helps in reducing incidence of cardiac disease (Mintz et al., 1995). The iron content of the water samples in this study is in line with NSDWQ standard of $0.3 \mathrm{mg} / 1$ (NSDWQ, 2007). The chlorine content of the stored water ranges from $4.31 \pm 0.71$ to $19.68 \pm 0.90 \mathrm{mg} / 1$ and $7.02 \pm 0.86$ to $22.78 \pm 0.86 \mathrm{mg} / \mathrm{l}$ for week 0 and week 3 respectively.

Chlorine content in Sample A and B reduced as storage increased which was the same for Sample C which increased with time. Conductivity, sulphates, nitrates and phosphates reduced as storage increased in all the samples. The physiochemical parameters were compared to Nigeria Standard of Drinking Water Quality. The total bacterial counts for all the water samples were generally high and exceeded the limit of $1.0 \times 10^{2} \mathrm{cfu} / \mathrm{ml}$ which is the standard limit of heterotrophic count for drinking water (NSDWQ, 2007).

Table 1: Physicochemical parameters of borehole water sample During Storage over a period of 3 weeks.

\begin{tabular}{|c|c|c|c|c|c|c|c|}
\hline \multirow[b]{2}{*}{ Parnmeters } & \multicolumn{2}{|c|}{ Sample A } & \multicolumn{2}{|c|}{ Sample B } & \multicolumn{2}{|c|}{ Sample C } & \multirow{2}{*}{$\begin{array}{l}\text { NSDWQ } \\
\text { Maximum } \\
\text { Stand ard }\end{array}$} \\
\hline & week0 & w eek 3 & week 0 & week 3 & week 0 & w eek 3 & \\
\hline $\mathrm{pH}$ & $5.45 \pm 0.04$ & $5.33 \pm 0.03$ & $6.6 \pm 0.06$ & $6.47 \pm 0.97$ & $5.51 \pm 0.05$ & $5.59 \pm 10$ & $6.5-8.5$ \\
\hline $\mathrm{EC}, \mathrm{us} / \mathrm{cm}$ & $18.33 \pm 2.52$ & $26.6 \overline{6} \pm 3.51$ & $57 . \overline{67} \pm 2.65$ & $67.00^{-} \pm 23.43$ & $12.67 \pm 2.08$ & $20.6 \overline{6} \pm 2.52$ & 1000 \\
\hline $\mathrm{C} 1, \mathrm{mg} / 1$ & $6.23 \pm 1.36$ & $9.06 \pm 1.19$ & $19.68 \pm 0.90$ & $22.78 \pm 0.86$ & $4.31 \pm 0.71$ & $7.02 \pm 0.86$ & 250 \\
\hline TSS, mg/1 & $0.37 \pm 0.10$ & $1.06 \pm 0.07$ & $1.15 \pm 0.11$ & $2.68 \pm 0.05$ & $0.25 \pm 0.08$ & $0.82 \pm 0.05$ & NS \\
\hline $\mathrm{TDS}, \mathrm{mg} / 1$ & $9.16 \pm 1.26$ & $13.33 \pm 1.76$ & $98.83^{-} \pm 1.32$ & $33.5 \pm 1.26$ & $6.33 \pm 1.04$ & $10.33 \pm 1.26$ & 500 \\
\hline Turbidity, ntv & $0.11 \pm 0.02$ & $0.24 \pm 0.02$ & $0.36 \pm 0.02$ & $0.60 \pm 0.02$ & $0.07 \pm 0.02$ & $0.18 \pm 0.02$ & 5 \\
\hline $\mathrm{BOD}, \mathrm{mg} / 1$ & $1.24 \pm 0.20$ & $2.12 \pm 0.70$ & $2.51 \pm 0.21$ & $5.35 \pm 0.11$ & $0.59 \pm 0.1$ & $1.65 \pm 0.05$ & NS \\
\hline $\mathrm{SO}_{4}{ }^{2}, \mathrm{mg} / 1$ & $4.93 \pm 0.73$ & $7.73 \pm 0.95$ & $15.5 \pm 0.77$ & $19.43 \pm 0.27$ & $1.72 \pm 0.00$ & $5.99 \pm 0.68$ & 100 \\
\hline $\mathrm{NO}_{3}^{-}, \mathrm{mg} / 1$ & $3.3 \pm 50$ & $5.33 \pm 0.63$ & $10.38 \pm 0.53$ & $13.4 \pm 0.45$ & $3.42 \pm 0.42$ & $4.13 \pm 0.45$ & 50 \\
\hline $\mathrm{PO}_{3}, \mathrm{mg} / 1$ & $1.1 \pm 0.23$ & $2.4 \pm 0.21$ & $3.46 \pm 0.24$ & $6.03 \pm 0.15$ & $2.28 \pm 0.19$ & $1.86 \pm 0.15$ & 50 \\
\hline $\mathrm{NH}_{3}{ }^{+}, \mathrm{mg} / 1$ & $0.06 \pm 0.20$ & $0.1 \overline{8} \pm 0.01$ & $0.19 \pm 0.02$ & $0.45 \pm 0.01$ & $0.76 \pm 0.02$ & $0.41 \pm 0.01$ & 0.2 \\
\hline $\mathrm{Ca}^{2+}, \mathrm{mg} / 1$ & $0.44 \pm 0.07$ & $0.72 \pm 0.85$ & $1.43 \pm 0.07$ & $1.73 \pm 0.06$ & $0.04 \pm 0.06$ & $0.55 \pm 0.06$ & 0.4 \\
\hline $\mathrm{Mg}^{2+}, \mathrm{mg} / 1$ & $0.04 \pm 0.01$ & $0.11 \pm 0.01$ & $0.12 \pm 0.01$ & $0.31 \pm 0.01$ & $0.03 \pm 0.01$ & $0.08 \pm 0.01$ & 0.2 \\
\hline $\mathrm{Na}^{2+}, \mathrm{mg} / 1$ & $1.61 \pm 0.45$ & $48 \pm 0.31$ & $5.07 \pm 0.48$ & $17.06 \pm 0.22$ & $0.32 \pm 0.37$ & $3.72 \pm 0.22$ & 200 \\
\hline $\mathrm{Zn}^{2+}, \mathrm{mg} / 1$ & $0.21 \pm 0.04$ & $0.4 \overline{2} \pm 0.04$ & $0.65 \pm 0.04$ & $1.07 \pm 0.03$ & $0.14 \pm 0.04$ & $0.33 \pm 0.03$ & 3 \\
\hline $\mathrm{Cu}^{2+} \mathrm{mg} / 1$ & $0.18 \pm 0.03$ & $0.26 \pm 0.04$ & $0.60 \pm 0.03$ & $0.67 \pm 0.03$ & $0.15 \pm 0.02$ & $0.20 \pm 0.03$ & 1 \\
\hline $\mathrm{Cr}^{2+}, \mathrm{mg} / 1$ & $0.07 \pm 0.01$ & $0.11 \pm 0.02$ & $0.23 \pm 0.01$ & $0.27 \pm 0.01$ & $0.06 \pm 0.01$ & $0.08 \pm 0.01$ & 0.05 \\
\hline $\mathrm{Fe}^{2+}, \mathrm{mg} / 1$ & $0.20 \pm 0.03$ & $0.29 \pm 0.04$ & $0.61 \pm 0.03$ & $0.74 \pm 0.03$ & $0.15 \pm 0.02$ & $0.22 \pm 0.03$ & 0.3 \\
\hline
\end{tabular}




\begin{tabular}{llll}
\hline Week & Sample A & Sample B & SampleC \\
\hline $\mathbf{0}$ & $2.16 \pm 0.37$ & $4.01 \pm 0.57$ & $3.74 \pm 0.12$ \\
$\mathbf{1}$ & $1.66 \pm 0.31$ & $4.7 \pm 0.46$ & $6.16 \pm 0.61$ \\
$\mathbf{2}$ & $4.36 \pm 0.42$ & $6.76 \pm 0.61$ & $7.11 \pm 0.82$ \\
$\mathbf{3}$ & $1.30 \pm 0.15$ & $2.33 \pm 0.21$ & $3.09 \pm 0.31$ \\
\hline
\end{tabular}

Table 3: Total Coliform bacteria Count in Borehole Water During Storage in Jerry Can $\left(10^{4} \mathrm{cfu} / \mathrm{ml}\right)$.

\begin{tabular}{llll}
\hline Week & Sample A & SampleB & Sample C \\
\hline $\mathbf{0}$ & $1.00 \pm 0.30$ & $6.57 \pm 0.93$ & $6.13 \pm 0.12$ \\
$\mathbf{1}$ & $3.30 \pm 0.40$ & $7.43 \pm 0.67$ & $2.61 \pm 0.82$ \\
$\mathbf{2}$ & $6.33 \pm 0.57$ & $8.70 \pm 1.01$ & $8.95 \pm 1.00$ \\
$\mathbf{3}$ & $2.13 \pm 0.21$ & $3.63 \pm 0.31$ & $4.26 \pm 0.42$ \\
\hline
\end{tabular}

Table 4: Cultural, morphological and biochemical characterization of Bacteria isolates in borehole water samples

\begin{tabular}{llllll}
\hline Test & Org 1 & Org 2 & Org 3 & Org 5 & Org 6 \\
\hline Shape & Circular & Round & Round & Round & Round \\
Color & Milky & Creamy & Cream & Cream & Orange \\
Margin & Entire & Entire & Entire & Red & Lobate \\
Opaque & Opaque & transluscent & Opaque & Transparent & Opaque \\
Elevation & Flat & Flat & Flat & Flat & Flat \\
Weyldry & Wet & Wet & Wet & Wet & Wet \\
Gram reaction & - & + & - & - & + \\
Shape & Rod & Cocci & Baccilli & Cocci & Baccilli \\
Arrangement & Single & In clusters & Single & Chains & Single \\
Catalase & + & + & + & + & + \\
Oxidation & - & - & - & - & + \\
Indole & & - & + & - & + \\
Urease & - & - & - & - & - \\
Citrate & - & - & - & - & - \\
Coagulase & & + & - & - & - \\
Spore & + & - & - & - & + \\
Fermentation & & & & & \\
Lactose & + & + & + & + & + \\
Sucrose & + & - & + & - & + \\
Sorbitol & - & - & - & - & + \\
Glucose & + & + & + & + & + \\
Manitol & - & - & + & - & + \\
Probable & Pseudom & Stcophylocc & Escheric & Serretia spp. & Bacilli \\
Isolate & onas & us & hia coli & & us \\
& arrugino & epidermidis & & & cereus \\
& sa & & & & \\
\hline
\end{tabular}

Table 5: Distribution of Bacterial isolate in Borehole Water Samples

\begin{tabular}{lll}
\hline Bacteria isolates & $\begin{array}{l}\text { Frequency of } \\
\text { occurrence }\end{array}$ & $\begin{array}{l}\text { Percentage of } \\
\text { occurrence (\%) }\end{array}$ \\
\hline Bacillus cereus & 5 & 13.8 \\
Escherichia coli & 11 & 30.5 \\
Pseudomonas afxuginosa & 7 & 19.4 \\
Staphylococcus epidexouidis & 9 & 25 \\
Sexxetia spp. & 4 & 11.1 \\
\hline
\end{tabular}

Table 6: Bisphenol A Composition in Borehole Water samples over time

\begin{tabular}{|c|c|c|c|c|c|c|}
\hline \multirow{2}{*}{$\begin{array}{l}\text { BPA Composition } \\
(\mathrm{mg} / \mathrm{L})\end{array}$} & \multicolumn{2}{|c|}{ Sample A } & \multicolumn{2}{|c|}{ Sample B } & \multicolumn{2}{|c|}{ Sample C } \\
\hline & week 0 & week 3 & week 0 & week 3 & week 0 & week 3 \\
\hline Methylene Chloride & 0 & $0.026 \pm 0.027$ & 0 & $0.024 \pm 0.027$ & 0 & $0.054 \pm 0.033$ \\
\hline Benzene & 0 & $0.016 \pm 0.004$ & 0 & $0.021 \pm 0.020$ & 0 & 0 \\
\hline Dichlorobenzene & 0 & $0.053 \pm 0.022$ & 0 & $0.046 \pm 0.031$ & 0 & $0.055 \pm 0.062$ \\
\hline Hexane & 0 & 0 & 0 & 0 & 0 & 0 \\
\hline Vinyl Chloride & 0 & 0 & 0 & 0 & 0 & 0 \\
\hline Tetrachlorgethylene & 0 & 0 & 0 & 0 & 0 & 0 \\
\hline Toluene & 0 & 0 & 0 & 0 & 0 & 0 \\
\hline
\end{tabular}


The count is indicative of the presence of organic and dissolved salts in the water. From the result above, it was observed that in all water samples the mean total heterotrophic bacteria count ranges from $1.00 \pm 0.30$ x $10^{4}$ to $2.13 \pm 0.21 \times 10^{4} \mathrm{cfu} / \mathrm{ml}$ in Sample A, $3.63 \pm$ $0.31 \times 10^{4}$ to $8.70 \pm 1.01 \times 10^{4} \mathrm{cfu} / \mathrm{ml}$ in Sample B and $2.61 \pm 0.82 \times 10^{4}$ to $8.95 \pm 1.00 \times 10^{4} \mathrm{cfu} / \mathrm{ml}$ in Sample C which had the highest count (Table 2). The total coliform counts for all samples were exceedingly higher than the NSDWQ of maximum contamination level (MCL) for coliform bacteria in drinking water (NSDWQ, 2007). The high coliform count obtained in the samples may be an indication that the water sources are faecally contaminated (Obi and Okocha, 2007). None of the water samples complies with NSDWQ standard for coliform in water. Bacteria isolated from all water samples include bacillus cereus, serretia spp., Escherichia coli, Pseudomonas aeruginosa, Streptococcus faecalis, and Staphylococcus epidermidis which are also of public health significance. Staphylococcus epidermidis is known to produce enterotoxin (Aydin, 2007). The presence of coliform indicates that all water samples are not fit for drinking and the observation in this study suggest that high heterotrophic count in water reflects high coliform count. Presence of high coliform count in borehole water samples could be attributed to the proximity of the borehole near to a septic tank at a distance less than the $30 \mathrm{~m}$ recommended by NSDWQ. The results above shows that the coliform population increased with time. There was alternate increase and decrease of Bacteria count in samples $\mathrm{C}$ as storage progresses this is in contrast to Orji et al. (2006) who recorded a direct increase of Bacteria count. Bisphenol A analysis at week zero shows that no BPA contingents were detected in all the water samples, but at week 3 there were detectable quantities of BPA components. This indicates that temperature and storage duration is a major factor in Bisphenol A degradation in storage tanks (Table 6). The composition of Bisphenol A found in week 3 is enough to cause serious health hazards when accumulated in the body. The BPA detected in this research work is in line with Vandenberg et al. (2007) who recorded increase in Bisphenol A contingents as storage time increases. The presence of potential pathogens such as Escherichia coli, Pseudomonas aeruginosa, Serretia spp. and Staphylococcus epidermidis (Table 4) in the water samples indicates the absence of sanitation on the part of the users.

Conclusion: This study shows that storage of water overtime leads to increased leaching of BPA which will encourage the proliferation of bacteria and also affect its physicochemical properties. In comparism to NSDWQ standard, all water samples studied were not fit for drinking. High temperature and a prolonged storage have been implicated in the increased release of BPA in water tanks. Hence plastic borehole overhead tanks should not be directly exposed to the atmosphere as direct rays of the sun leads to fast leaching of toxic chemicals. This research has shown that there is need for an improvement in disinfection and cleaning of storage tanks, hence drinking water should be stored and used within days. There is also need for public awareness programmes to educate the public on the possible health implications of drinking water which has been stored for a prolonged time.

\section{REFERENCE}

Atuanya, E. I., Adeghe, M. O. and Udochukwu, U. (2016). Bioavailability of Plastic Contaminants and Their Effects on Plastic Bottled and Sachet Drinking Water Supplies. British Microbiology Research Journal, 14(4): 1-10.

Adeghe, O.M. and Emejulu, M.J. (2016). Evaluation of Bisphenol A, Physiochemical Properties and Microbial Characterization of Borehole Water Stored in Plastic Containers. Journal of Applied Science and Environmental Management, 20 (4):1119-1124

Aydin, A. (2007). The microbial and physicochemical quality of ground water in west Thrace Turkey. Polish Journal of Environmental Studies, 16 (3): 377-383.

Ballester, F. and Sunyer, J. (2000). Drinking water and gastrointestinal disease, need of better understand and an improvement in public health surveillance. Journal of Epidemiology of Community Health, 54:3-5.

Biles J.E., Mc Neal T.P., Begley T.H. (1997). Determination of bisphenol $A$ in reusable polycarbonate food-contact plastics and migration to food-simulating liquids. Journal Agricultural Food Chemistry, 45: 3541-3544.

Carwile J.L., Luu H.T., Bassett L.S., Driscoll D.A., Yuan C., Chang J.Y., Ye, X., Calafat A.M., Michels K.B. (2009). Polycarbonate bottle use and urinary Bisphenol A concentrations. Environmental and Health Perspectve, 117: 1368-1372.

Cheesbrough M. (2000). Bacteriological testing of water: In District Labouratory Practicein Tropical Countries. Part 2:149-154. 
Del-Olmo M., Gonzalez-Casado N.A. and Navas J.L. (1997). Determination of bisphenol A (BPA) in water by gas chromatography-mass spectrometry. Anal Chimica Acta 346: 87-92.

Dean, J.R., and Xiong, G. (2000)."Extraction of organic pollutants from environmental matrices selection of extraction technique", Trends in Analytical Chemistry, 19(9): 553-564.

Dolinoy, D.C, Huang D. and Jirtle R.L. (2007). Maternal nutrient supplementation counteracts bisphenol A-induced DNA hypomethylation in early development. Processes of National Academic Science USA, 104 (32): 56-61.

Eniola K.I.T., Olayemi A.B., Awe S., Adegoke A., Osanoto I.B., Abolade G.O. and Kayode-Isola T.M. (2006). Effect of Storage on Bacteriological Quality of Well Water. African Journal of Clinical and Experimental Microbiology, 1:567pp.

Food and Agriculture Organisation (1997). Chemical analysis manual for food and water, 5 th Ed, FAO Rome. pp 20-26.

Garrity, G.M., Brenner, D.J., Krieg, N.R., and Staley J.T. (2005). Bergey's Manual of Systematic Bacteriology, 2nd ed., Springer, New York 123 pp.

Holt, J.G., Krieg, N.R., Sneath, P.H.A., Staley, J.T. and Williams S.T. (2000). Bergey's Manual of Determinative Bacteriology, 9th ed. Lippincott, Williams and Wilkins, Philadelphia, PA 234pp.

Jagals, P., Bokaka, T. C. and Grabow W. O. K (1999). Changing consumer water patterns and their effect on microbiological water quality as a result of an engineering intervention. Water South Africa. 25 :297-300.

Kawamura, Y., Koyano, Y., Takeda, Y. and Yamada, Y. (1999). Journal Food Hygiene Society. Jpn, 206p.

Lamikara, A. (1999). Essential microbiological for students and practitioners of pharmacy, medicine and microbiology, 2nd Edition, Amkra books, 406pp.

Madigan, M. T., Martinko, J. M. and Parker, J. (2000). Brock Biology of Microorganisms. Prentice Hall Press, USA.p.32.
Marque, S., Jacqmin-Gadda, H., Dartigues, J.F. and Commenges D. (2003). Cardio-vascular mortality and calcium and magnesium in drinking water: an ecological study in elderly people. European Journal of Epidemiology, 18: 305-309.

Mintz, E. D. Reiff, E. M, Tauxe and R.V. (1995). Safe water treatment and storage in home: A practical new strategy to prevent water borne diseases. JAMA, 273: 948-953.

Moriyama K., Tagami T., Akamizu T., Usui T., Saijo M., Kanamoto N., Hataya Y., Shimatsu A., Kuzuya H., Nakao K. (2002). Thyroid hormone action is disrupted by Bisphenol A as an antagonist. Journal Clinical Endocrinologic Metabolism, 87: 5185-5190.

Morrissey R.E., George J.D., Price C.J., Tyl R.W., Marr M.C. and Kimmel C.A. (1987). The developmental toxicity of bisphenol A in rats and mice. Fundamental Application on Toxicology, 8: 571-582

NSDWQ, (2007). Nigeria Standard for Drinking Water Quality .Nigeria Industrial Standard Approve by Standard Organization of Nigeria Governing Council. ICS13.060.20:15-19.

Obi, C.N. and Okocha, C.O. (2007). Microbiological and physicochemical analyses of selected borehole waters in World Bank Housing Estate, Umuahia, Abia state Nigeria. Journal of Engineering and applied Sciences, 2 (5): 920-929.

Okonko, I.O, Adejoje, O.D, Ogunnusi, T.A, Fajobi, E. and Shittu, O.B. (2009). Microbiological and physicochemical analysis of different water samples used for domestic purposes in Abeokuta and Ojota, Lagos Nigeria .African Journal of Biotechnology, 7 (5): 617-621.

Orji, M. U., Ezenwaje, E. E; Anyaegbunam, B. C. (2006). Spatial appraisal of shallow water well water pollution in Awka, Nigeria. Nigeria journal microbiology, 20:1389-1394

Rajini K. Roland P. John C.and Vincent R (2010) .Microbiological and physicochemical analysis of drinking water in George Town. Nature and Science, 8(8)261-265.

Sobsey, M.D. (2002).Drinking water and health research:a look to the future in the United States and globally. Journal of Water and Health, 4: 1721. 
Soto A.M, Justicia H, W ray J. W, Sonnenschein, C. (2005) .p-Nonyl-phenol: anestrogenic xenobiotic released from "modified" polystyrene. Environmental Health Perspectives, 92:167-173.

Staples C.A., Dorn P.B., Klecka G.M., O’Block S.T., Harris L.R. (1998). Quantitative determination of bisphenol-A in river water by coolon-column injection-gas chromatography-mass spectrometry. International journals on Environmental Analysis of Chemical 69:83-98.
US Environmental protection Agency (USEPA) (1995). Guidelines for water supply $7^{\text {th }}$ edition. NewYork: WHO press pp.144-162?

Vandenberg L.N, Schaeberle C.M, Rubin B.S, Sonnenschein C, Soto A.M. (2007). The male mammary gland: a target forth exenoestrogen bisphenol A. Reproductive Toxicology. 37:15-23.

WHO. (2005). Financial management of water supply and sanitation. World Health Organization. Geneva, p.56. 